\title{
ANALYTICAL EVALUATION OF THE EXPORT OF MEDICINAL PLANTS FROM UKRAINE
}

\begin{abstract}
Certain aspects of the export of medicinal plants from Ukraine have been investigated in the article. Sales of medicinal plants abroad in the period from 2006 to 2020 in-kind and monetary worth have been analyzed. The geographical structure of export of Ukrainian medicinal plants and the structure of export of medicinal plants from Ukraine by species has been studied. The characteristic positive and negative tendencies inherent in the export of medicinal plants from Ukraine has been revealed and generalized. Importance of medicinal plant production for the national economy of Ukraine, the ability to partially meet the demand for medicinal plants in the world, in particular in European countries, and the factors that determine the economic feasibility of given production has been emphasized.
\end{abstract}

Keywords: medicinal plant production, export capacity, evaluation of the market, structure of export of medicinal plants.

\section{INTRODUCTION}

There is information that there are about 320 thousand species of plants in the world. Of these, 3 thousands are a source of food, 5 thousands are used for industrial purposes, 15 thousands as ornamental plants, 25 thousands for medicinal purposes, and others are used for various needs. There is also a claim that there are 422 thousands flowering plants in the world and 72 thousands of them are used for medicinal purposes. Beyond that, studies by Karik U., Tunçtürk M. (2019) show that 900 species of medicinal plants in the world are grown for commercial purposes and that the production of medicinal plants, including essential oily and spicy, in the modern global agro-industrial complex is considered to be one of the most profitable. Export-import of medicinal plants in the world is also widely developed in today's conditions. Thus, Mafimisebi, T. (2013), studying the international market of medicinal plants and products of their processing, points out that it is very voluminous. Medicinal plants, including essential oily and spicy are sold both as raw materials and as processed final products. Demand for these products is growing rapidly, as new directions of medicinal plants uses are constantly appear and these markets are

\footnotetext{
1 Tetiana Mirzoieva, PhD, Department of Economy of enterprise named after prof. I.N. Romanenko, National University of Life and Enviromental Sciences of Ukraine (corresponding author); e-mail: mirzoeva2018@ukr.net. ORCID: 0000-0002-0034-6138.

2 Oleksandr Nechyporenko, DSc PhD, vise director on scientific work, National Scientific Center "Institute of Agrarian Economy"; e-mail: o.nechyporenko57@gmail.com. ORCID: 0000-0002$-1080-5633$.
} 
constantly expand. World Bank experts note that global demand for medicinal plants, especially as raw materials for more complex final products, has been growing steady since the turn of the century, and the World Health Organization forecasts that the global herbal market will grow to \$ 5-7 trillion until 2050 (Medicinal and Aromatic Plants, 2018). The largest suppliers to the world market of medicinal plants from Asia are China and India, from Africa - Morocco, from Europe - Poland, Bulgaria and Albania, from South America - Chile and Peru. The largest consumers of medicinal plants in the world are the United States, Japan and Europe. Thus, it is known that in Japan $90 \%$ of the population use medicinal plants in nutrition and treatment of various diseases (Rokhsareh Asl Roostaa, Reza Moghaddasib, Seyed Safdar Hosseini, 2017). Today, European market is considered to be one of the world's largest commercial medicinal plants and plant-origin medicines markets. European countries not only import, but also produce a wide range of medicinal plants and medicines based on plant raw material. European consumers, for example in France, Germany, Italy, Sweden and England, often use medicinal plants as an adjunct to medication treatment (Mirzoieva, 2013).

Thus, in today's conditions, medicinal plant production plays an important role in the world economy and in fact has become a separate export-oriented direction of production activity. In Ukraine, despite the fact that medicinal plant production has a stable export orientation in recent years, this branch is not a priority sector of the economy. As a result, the share of medicinal plants is teeny in the total state export. At the same time drawing attention to the fact that while exporting agricultural sector products, first of all Ukraine sells abroad grain, world prices for which have been falling steady in recent years, it would be useful to move to a multi-purpose export policy. In particular, if we consider that worldwide export of cultivated medicinal plants is an extremely promising area of the economy, it is necessary to study trends in export of medicinal plants from Ukraine to determine the existing potential. Therefore, the purpose of this research is to analyze Ukrainian export of medicinal plants and to identify its characteristic trends.

\section{METHODOLOGY OF RESEARCH AND RESULTS}

The study was practical in nature and was conducted using the method of scientific comparison, descriptive-analytical method and the method of statistical analysis. The method of scientific generalization was used to formulate the conclusions of the research.

Ukraine having a huge potential, now is the 44th in the world ranking of exporters of medicinal plant products. According to experts, the state does not use the export potential practically in the market of medicinal plants (Ukraine practically does not use..., 2018). Nevertheless, Ukrainian export of medicinal plants has been characterized by a number of positive trends during recent years.

The average annual indicator of export of medicinal plants from Ukraine in 2010-2020 fluctuated within about 3 thousand tons of products (Fig. 1). At the same time, the largest export increase was observed in $2019-4.39$ thousand tons or 12.08 million dollars. USA, which is 2.2 times more in-kind and 3.6 times more in monetary worth , compared to 2010 (Market Review, 2020, 2018).

The largest collapses of export of medicinal plants from Ukraine were in 2006 and 2014. After the collapse in 2014, since 2015 there has been a gradual increase in export of medicinal plants from Ukraine. Thus, in the period from 2014 to 2019, the export of medicinal plants from Ukraine increased by $87.6 \%$ in-kind. It can be explained by the fact 
that in recent years European companies, realizing that Ukrainian medicinal plant raw materials are more cost-effective for them and have a high concentration of active substances, began to buy it actively from Ukrainian producers and intermediaries.

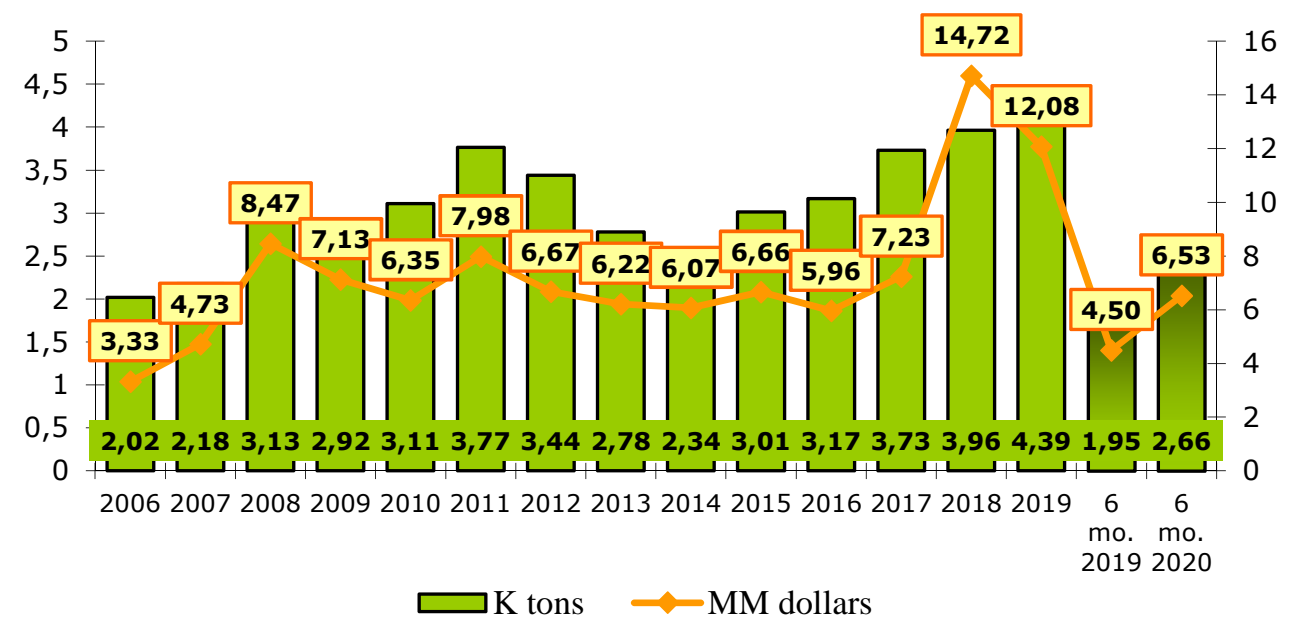

Fig. 1. Dynamics of export of medicinal plants from Ukraine in 2006-2020, thousands of tons, millions of USA dollars

Source: (Market Review...., 2020, 2018. Author's own depiction).

In turn, export of medicinal plants from Ukraine in monetary worth in 2019 increased by $99 \%$ compared to 2014. A significant increase in export of medicinal plants in monetary worth indicates that Ukrainian producers have begun to produce higher quality products that meet the foreign buyer's needs. At the same time, drawing attention to the fact that Ukraine is unique for its great variety of medicinal plants, experts point out that the country is able to increase export of given products (Lavender Plantation will pay off in 2 years, 2018, Stepanushko, 2018).

According to the statistics, in 2010-2011 the biggest consumers of Ukrainian medicinal plants were Poland and Russia, in 2012-2013 - Austria, Poland and Russia. In 2014, Germany joined the leading countries-consumers of Ukrainian plant raw materials. In 2015, among the three leaders in the overall export structure of medicinal plants from Ukraine were Poland $-38.51 \%$, Latvia $-14.83 \%$ and Germany $-13.06 \%$ (Fig. 2).

Export of Ukrainian medicinal plants to Germany, which is a major player in the area of medicinal plants in the world, has been growing in recent years. This is due to the fact that any other European country doesn't consume as many medicinal herbs as Germany in recent years, doctors and patients in Germany more and more preferred natural rather than chemical medication. When Germans come to the pharmacy without a prescription, three-quarters firstly ask about herbal medicines (Medicinal Herbs, 2008). In addition, German inhabitants do not drink usual for Ukrainians green or black tea, they prefer herbal teas. And since some species of plants are threatened with extinction in Germany itself, German producers are looking for medicinal plant raw materials outside their country. 
Currently, experts point out that Germany is ready to buy 40,000 tons of medicinal plants a year in Ukraine.

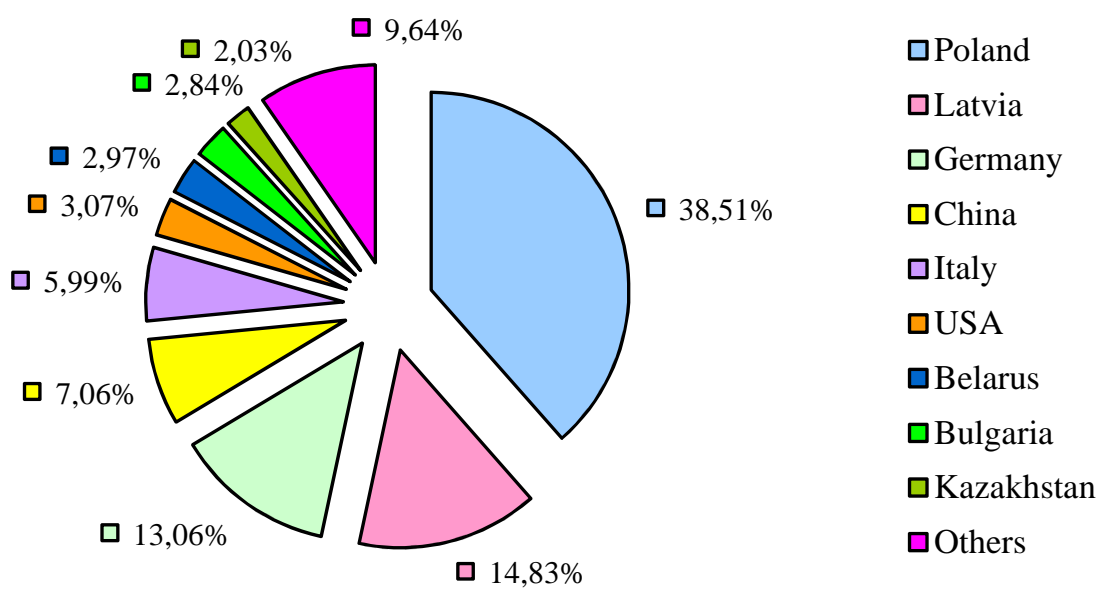

Fig. 2. Geographical structure of export of medicinal plants from Ukraine in 2015, \% (in-kind) Source: (Market Review..., 2020, 2018. Author's own depiction).

According to the analysis of the geographical export structure of medicinal plants from Ukraine in 2020 the largest buyers of domestic medicinal plants in-kind were Poland (35.48\%), China (13.63\%), Latvia (11.01\%) and, again, Germany (8.7\%) (Fig. 3).

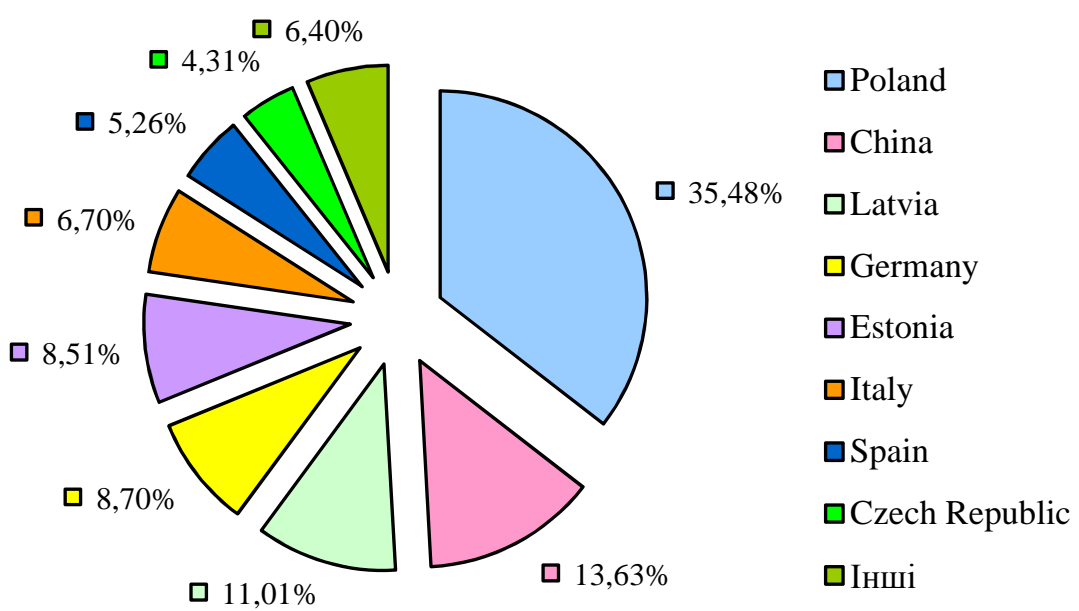

Fig. 3. Geographical structure of export of medicinal plants from Ukraine in 2020, \% (in-kind) Source: (Market Review..., 2020, 2018. Author's own depiction). 
According to experts, in the future the demand from Europe for Ukrainian medicinal plants will only increase. The marginalization of such production depends on both individual crops and demand from importing countries. Thus, Yevhenii Shumeiko, owner of the Ukrainian company "Dobrotrav", which specializes in cultivation and harvesting high-quality medicinal plant raw materials, notes that a significant number of medicinal plants are popular on the European market -they are elderberries, lime blossom, nettle leaves, marshmallow root, burdock root, Echinacea root and herb, dandelion root and leaf, birch leaf, coltsfoot leaf, plantain leaf and others. (Demand is growing in Europe, 2018).

The rapidly increasing demand for medicinal herbs in the world is largely due to the fact that European producers are gradually abandon their cultivation and prefer to buy finished raw materials in developing countries, including Ukraine, in order to resell it to other countries or for production of value-added products on a plant basis. For example, Poland and Bulgaria, which until recently traditionally specialized in cultivation and harvesting medicinal plants, are changing their references. It is assumed that these countries turn into importers from pure exporters of medicinal plants, including buying products in Ukraine and reselling them or products based on them to customers in Germany, the USA and Japan.

Information of fig. 4 shows that the most important batches of medicinal plants in 2020 in monetary worth were sent from Ukraine to Poland $(31.5 \%)$, Germany $(19.56 \%)$ and Latvia (15.15\%). Thus, during 2015-2020, export channels for the distribution of Ukrainian origin medicinal plants remain stable, which indicates a relatively well-established cooperation between domestic sellers and foreign buyers.

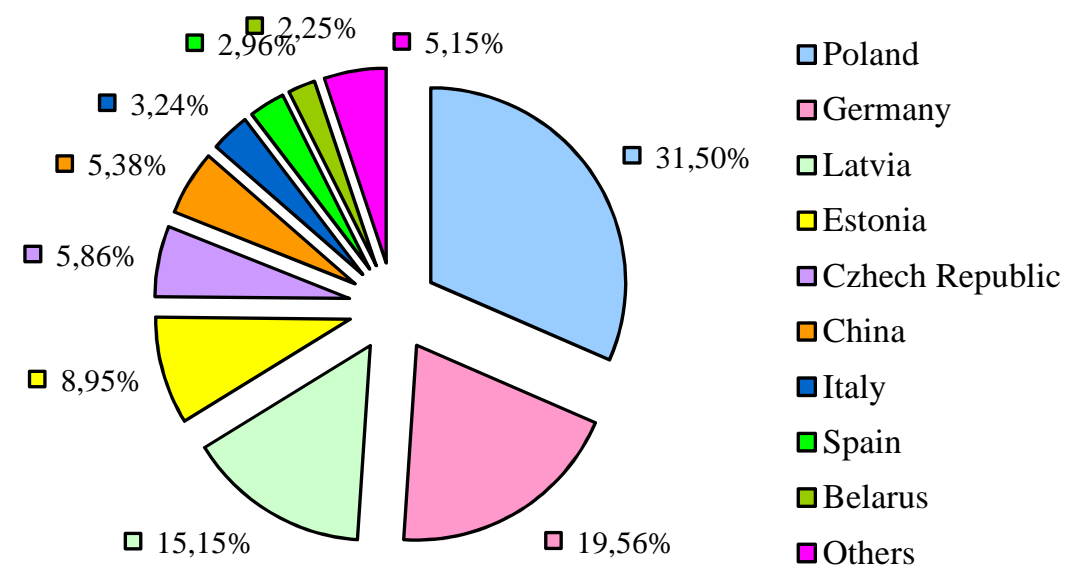

Fig. 4. Geographical structure of export of medicinal plants from Ukraine in 2020, \% (in monetary worth)

Source: (Market Review..., 2020, 2018. Author's own depiction).

The fact that the number of exporters of medicinal plant raw materials gradually increased we consider as positive: in 2012 there were 4 of them, in 2015 - 10, in $2018-30$. At the same time, it was found that $50-60 \%$ of all sales of Ukrainian medicinal plants in 
2020 account for 4-6 Ukrainian companies, two of which are large intermediaries, so this fact indicates that this segment in the structure of Ukrainian export is still extremely narrow.

The study revealed that the characteristic factors of Ukrainian export of medicinal plants are also: 1) $80 \%$ of export is wild ones; 2) there is almost no organic plant raw material, which has the biggest demand on the world market in today's conditions.

The backlog of Ukrainian producers in the direction of organic medicinal plants production gives a competitive advantage to the United States and Europe, since there are about $30 \%$ of the medicinal plants market are organic in there. Although, it should be noted that Ukraine is also actively increasing the export of organic products, in the which structure a significant share is falls on medicinal plants. Thus, according to the leading national certification body "Organic Standard", the main organic products (by volume) exported from Ukraine in 2017 were: corn, wheat, soybeans, barley, sunflower, millet, rapeseed, blueberries (frozen), oats, millet, lupine, apples (fresh), buckwheat, mustard, elderberry (fruit), pumpkin seeds, birch sap, flax, rye, walnut (kernel), sea buckthorn (frozen), blackberry (frozen), dog rose (frozen), coriander, peas, elderflower flowers (frozen), strawberry (frozen), cranberry (frozen), hawthorn (frozen), durum wheat flour, cranberry (frozen), mountain ash (frozen), chamomile (dried), hemp, raspberry (frozen) and sunflower oil (Ukraine is increasing..., 2018). In the next years and until 2020, the volume and list of exported organic products only increased. The list above shows that a significant part of organic products Ukraine export belongs to medicinal plants - lupines, elderberries, pumpkin seeds, coriander, flax, chamomile, etc., which reflects the presence of positive trends in the development of medicinal plants in general.

In general, the export of medicinal plants from Ukraine is currently characterized by: an increase in the number of exporting companies; purchases in Ukraine and export from Ukraine by Polish companies; increasing of the export amount from year to year, increasing of the export to Asia. In 2018, Ukraine had the 4th place in the volume of export of organic products to the EU, behind China, Ecuador and the Dominican Republic. According to the results of 2019, Ukrainian export of organic products to the European Union increased by $27 \%$ compared to 2018 or to 337.86 thousand tons and, accordingly, Ukraine ranked 2nd out of 123 countries in volume of export of organic products to the EU, up on two positions compared to the previous year (Ukraine - in second place..., 2020).

Analysis of the export structure of medicinal plants from Ukraine by species in 2015-2020 in-kind indicates that at the beginning of the study period the most sold plants abroad were chestnut (19.85\%) and blessed milk thistle (12.30\%) and a fairly wide list of others medicinal plants (Fig. 5). List of medicinal plants sold by Ukrainian producers and intermediaries abroad is broad enough to confirm once again the existence of demand for this product and Ukraine's ability to meet it. In 2020, indicated trends remained.

Analysis of the medicinal plants export structure by species in 2020 in-kind (Fig. 6) indicates that Ukrainian producers continued to sell a fairly wide range of products abroad. The leaders of sales at the end of the study period were chestnut and Echinacea - the percentage of the Echinacea in the overall export structure of medicinal plants from Ukraine in-kind in 2020 amounted to $8.36 \%$. Beyond that, domestic producers sell abroad large number of elderberry, birch buds and leaves, nettle, buckthorn bark, celandine, St. John's work, corn silk, horsetail, immortelle, sweet flag and other medicinal herbs. Wide range of medicinal plants that are sent abroad and accordingly to it are in demand is also a confirmation of the prospect and economic feasibility of their production and we believe 
it is another argument for the development of medicinal plants to come into the attention of the state.

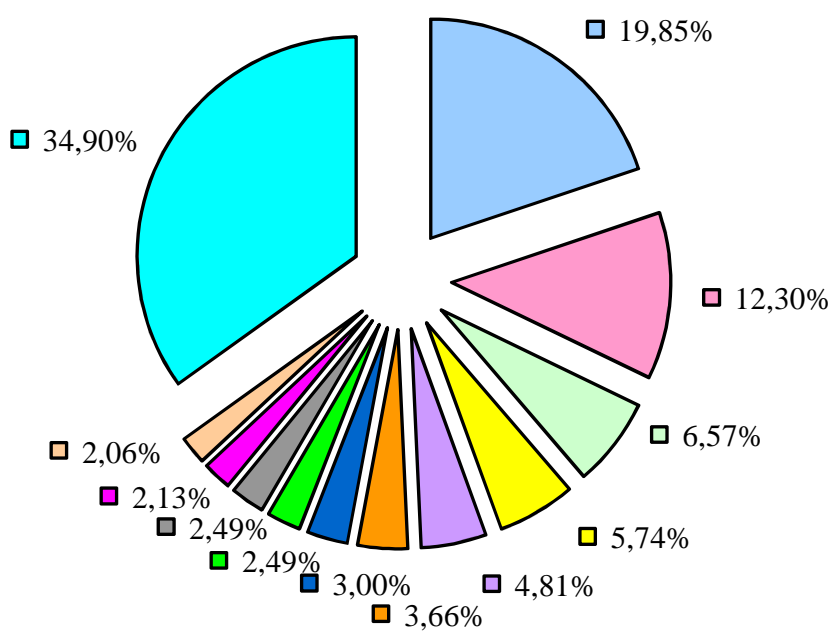

$\square$ cheastnut

口blessed milk thistle

口buckthorn bark

$\square$ elderberry

$\square$ echinacea

口birch buds and leaves

$\square$ immortelle

$\square$ corn silk

$\square$ oak bark

$\square$ marigold root

$\square$ nettle

口others

Fig. 5. Structure of export of medicinal plants from Ukraine by species in 2015, \% (in-kind) Source: (Market Review..., 2020, 2018. Author's own depiction).

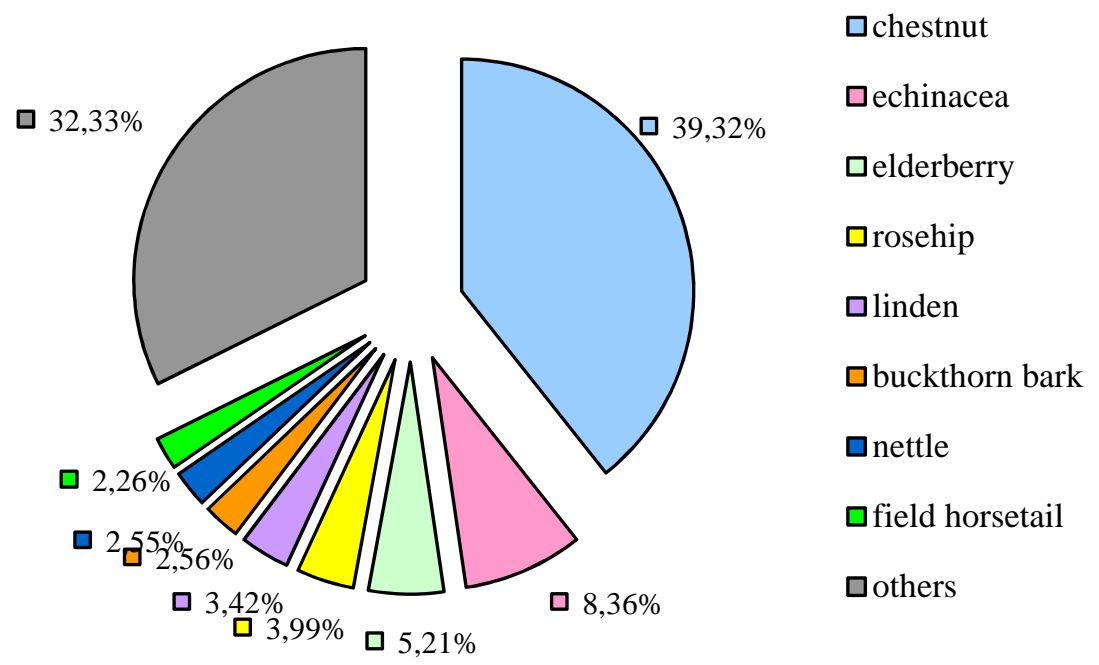

Fig. 6. The structure of export of medicinal plants from Ukraine by species in 2020, \% (in-kind)

Source: (Market Review..., 2020, 2018. Author's own depiction). 
Analyzing the structure of export of medicinal plants from Ukraine by species in monetary worth, in 2015, exporters received the biggest amount of money from the sales of elderberry (16.79\%), chestnut (7.39\%) and buckthorn bark (6.92\%) (Fig. 7). Blessed milk thistle was at the fourth place of cash proceeds $-6.87 \%$. These are plants on the basis of which a large number of medicines, disease prevention products and a number of healthy food around the world are produced.

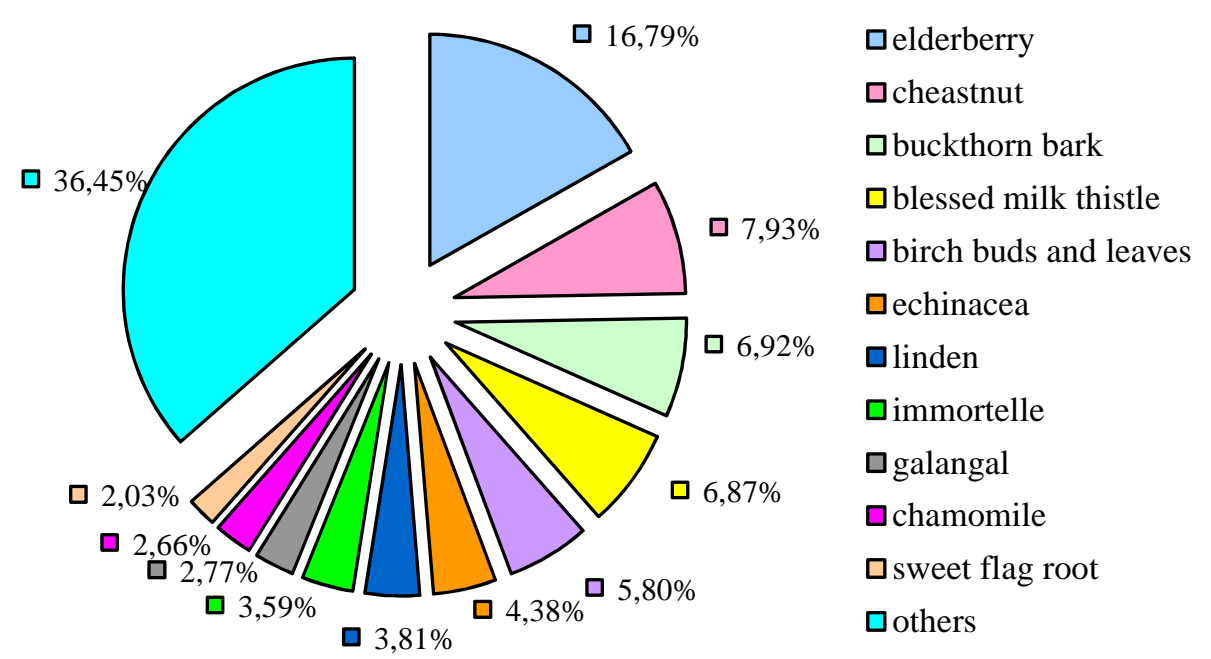

Fig. 7. Structure of export of medicinal plants from Ukraine by species in 2015 , \% (in monetary worth)

Source: (Market Review..., 2020, 2018. Author's own depiction).

In principle, the structure of export of medicinal plants from Ukraine by species in 2015 in monetary worth echoes with the structure of export of medicinal plants from Ukraine by species in-kind in the same year. That is, it can be noted that the largest profits producers receive by selling products in large quantities. In the same time the sale of high-value medicinal raw materials in small quantities may also be forward-looking. However, it is possible with the presence of modern technological methods of deep processing of medicinal plants, which is not present in the vast majority of Ukrainian producers in the area of medicinal plants at this stage of development. And intermediaries-buyers, as a rule, use their efforts for collect as large batches of goods as possible and send them abroad through the established channels. So the main problem of medicinal plant export from Ukraine is similar to the Ukrainian agricultural sector in general - producers mainly sell raw materials abroad, rather than the final product with high added value. We believe, the solution to this problem directly depends on the development and introduction of an effective strategy for the development of medicinal plants in the country.

In 2020, the situation with the export of medicinal plants from Ukraine has changed a bit. Thus, the largest in-kind export were chestnuts, Echinacea, elderberries, rose hips, and the most of monetary proceeds in the same year were received from export of chestnuts 
(27.14\%), lindens (22.58\%), elderberries (15.66\%), Echinacea (8.92\%) and lavender (6.93\%) (Fig. 8).

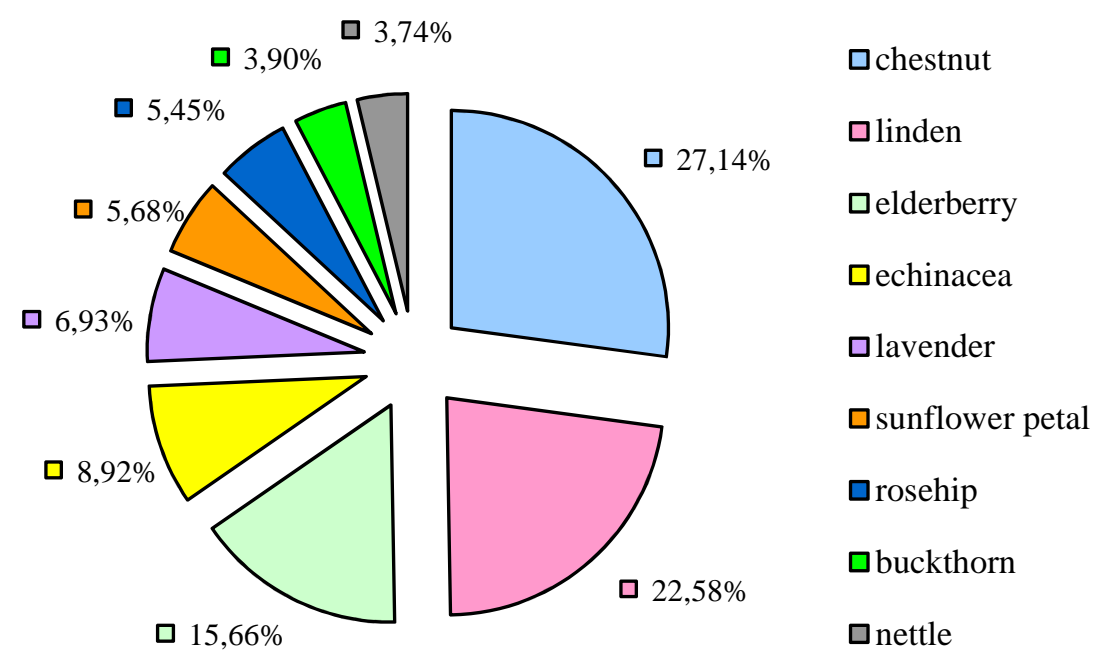

Fig. 8. Structure of export of medicinal plants from Ukraine by species in 2020, \% (in monetary worth)

Source: (Market Review..., 2020, 2018. Author's own depiction).

The last one, in particular the export of lavender, requires some comments. The matter is that the production of lavender in Ukraine is only gaining momentum and it is has not impregnated domestic market yet. Nevertheless, as we can see, some Ukrainian producers have started production of lavender in response to the significant demand for this crop and its essential oil from foreign consumers. The analysis of the structure of export of medicinal plants from Ukraine showed that these are actually niche crops to a large extent - those which can produce significant profits with small volumes of production.

It is necessary to note that the structure of export of medicinal plants by species is not something stable and constant. Need for certain type raw materials depend on the provision of it in the previous period and on the general trends in the consumption of medicinal plants in Ukraine and in the world. For example, in the CIS in today's conditions, the consumption of medicinal plants is declining due to impoverishment, but is increasing in Germany. Export-import volumes and prices for medicinal plants accordingly depend on weather conditions, the world harvest and tendencies in the processing enterprise's needs. Thus, in 2017, linden color price in Ukraine increased 2-2.5 times, due to the dry summer its main supplier Bulgaria had a crop failure (Stepanushko, 2018). This led to the linden taken the second place in the structure of export of medicinal plants from Ukraine by species in 2017 (in monetary worth) while in 2015 it took the seventh place.

Analyzing the export of Ukrainian medicinal plant raw materials, we cannot ignore the fact that the sale of medicinal plants abroad must be controlled by the state so it is no harm to the domestic vegetation, as is sometimes the case. In many countries of the world there 
is a critical situation with the resources of wild medicinal plants today because of excessive and sometimes uncontrolled procurement of medicinal raw materials. Thus, the uncontrolled collection and export of medicinal plants in general and extremely valuable ones in particular lead to the impoverishment of vegetation and to the degradation of agricultural land in the country.

\section{CONCLUSION}

In general, the analysis of export of Ukrainian medicinal plants revealed that: 1) its volumes are characterized by increase trends in monetary worth and in-kind; 2) the largest buyers of Ukrainian medicinal plants are Poland, Germany and Latvia, where is a stable constant demand for medicinal plants and products based on them; 3) Ukraine distributes a wide range of medicinal crops abroad; 4) a core of large permanent players has been formed within this segment in Ukraine.

Along with this, the main drawbacks in the field of export of medicinal plants from Ukraine were revealed: first, paying attention to the huge world demand for medicinal plant products and Ukraine's huge opportunities to partially meet it, the number of producers and exporters of medicinal plants in Ukraine is still extremely small; secondly, the largest profits Ukrainian producers receive by selling medicinal plants in large quantities, while the sale of high-value medicinal raw materials in small quantities may be forward-looking; thirdly, the main problem of export of medicinal plants from Ukraine is that inherent in the Ukrainian agricultural sector in general - producers sell abroad mainly raw materials, rather than the final product with high-added value.

Also, the analytical assessment of the export of medicinal plants from Ukraine testified to the prospects and economic feasibility for their production and is an argument that the development of medicinal plants came into the view of the state. Drawing attention to the important role which the sale of agricultural products abroad currently play in the development of the Ukrainian economy, the development of export of medicinal plants is also essential, as it will increase foreign income tothe state budget.

\section{REFERENCES}

Karik, U., Tunçtürk, M. (2019). Production, trade and future perspective of medicinal and aromatic plants in Turkey. Access on the internet: https://www.researchgate.net/publication/ 338080721_Production_Trade_and_Future_Perspective_of_Medicinal_and_Aromatic_Plants_ in_Turkey

Medicinal herbs: demand increases, control slacking (2008). Access on the internet: https://p.dw.com/p/D4dt

Mafimisebi, T.E. (2013). The Expanding Market for Herbal, Medicinal and Aromatic Plants In Nigeria and the International Scene. Access on the internet: https://www.omicsonline.org/openaccess/the-expanding-market-for-herbal-medicinal-and-aromatic-plants-in-nigeria-and-theinternational-scene-2167-0412.1000144.php?aid=21947

Medicinal and Aromatic Plants (2018). Access on the internet: http://documents1.worldbank. org/curated/en/496421556737648658/text/Medicinal-and-Aromatic-Plants.txt

Mirzoieva, T. (2013). Prospects for the development of medicinal crop production. Scientific Bulletin of the National University of Life and Environmental Sciences of Ukraine. "Economics, agricultural management, business". Vol. 181(6). 
Review of the market of medicinal plant raw materials of Ukraine 2020 (2020). Marketing Company "Sinergiia". Kyiv. 51 p.

Review of the market of medicinal plant raw materials of Ukraine2017 (2018). Marketing Company "Sinergiia". Kyiv. 40 p.

The lavender plantation will pay off in 2 years (2018). Access on the internet: http://agroportal.ua/

Rokhsareh Asl Roostaa, Reza Moghaddasib, Seyed Safdar Hosseini (2017). Export target markets of medicinal and aromatic plants. Access on the internet: https://isiarticles.com/ bundles/Article/pre/pdf/81751.pdf

Stepanushko, L. (2018). How company from Zhytomyr region manages to maintain it's position in the market of phytopreparations. Access on the internet: http://landlord.ua/

Demand for medicinal herbs of Ukrainian origin increases in Europe (2018). Access on the internet: https://superagronom.com/news/5782-z-yevropi-zrostaye-popit-na-likarski-traviukrayinskogo-pohodjennya

Ukraine is in second place in terms of exports of organic products to EU (2020). Access on the internet: https://www.ukrinform.ua/rubric-economy/3040089-ukraina-na-drugomu-misci-zaeksportom-organicnoi-produkcii-do-es.html

Ukraine is increasing export of organic products (2018). Access on the internet: https://www.epravda.com.ua/rus/news/2018/02/13/634019/

Ukraine almost does not use the export potential in the market of medicinal herbs (2018). Access on the internet: http://propozitsiya.com/ukraina-prakticheski-ne-ispolzuet-eksportnyypotencial-na-rynke-lekarstvennyh-trav

DOI: $10.7862 /$ rz.2020.mmr.29

The text was submitted to the editorial office: December 2020.

The text was accepted for publication: December 2020. 
